See discussions, stats, and author profiles for this publication at: https://www.researchgate.net/publication/297452926

\title{
A new synonym and new records of Tychiini (Coleoptera, Curculionidae) from Madeira Archipelago and Selvagens Islands
}

Article in Zootaxa. June 2008

Dol: 10.11646/zootaxa.1781.1.6

\section{CITATIONS}

3

2 authors:

Roberto Caldara

Independent Researcher

236 PUBLICATIONS 1,689 CITATIONS

SEE PROFILE
READS

84

Dora Pombo

Universidade da Madeira

74 PUBLICATIONS 320 CITATIONS

SEE PROFILE

Some of the authors of this publication are also working on these related projects:

Project entomology curculionidae View project

Project Revision of Afrotropical Cionus (Coleoptera, Curculionoidea) View project 


\title{
A new synonym and new records of Tychiini (Coleoptera, Curculionidae) from Madeira Archipelago and Selvagens Islands
}

\author{
ROBERTO CALDARA ${ }^{2} \&$ DORA AGUÍN-POMBO ${ }^{2,3}$ \\ ${ }^{1}$ Via Lorenteggio 37, 20146 Milan, Italy. E-mail: roberto.caldara@gmail.com \\ ${ }^{2}$ Department of Biology, University of Madeira, Campus da Penteada, 9000-390 Funchal, Madeira, Portugal. E-mail: aguin@uma.pt \\ ${ }^{3}$ CEM, Centre for Macaronesian Studies, Campus da Penteada, 9000-390 Funchal, Madeira, Portugal
}

Tychius bicolor Brisout, 1862 and Sibinia arenariae Stephens, 1831 are reported from the Archipelago of Madeira, respectively Madeira and Porto Santo, for the first time. Two additional specimens of T. filirostris Wollaston, 1854, known previously from only two specimens from Porto Santo, were examined. Following the study of these specimens and others from the Canary Islands (Tenerife, La Palma) and Selvagen Pequena, T. colonnellii Caldara, 1991 from Tenerife is proposed as a junior synonym of T. filirostris.

The archipelagos of Macaronesia (Madeira, Azores, Selvagens, Canary Islands and Cape Verde Islands) represent one of the richest areas for endemic species in Europe. Although some genera, especially of beetles, have there undergone considerable radiation, the tribe Tychiini, which in the Palaearctic region comprises about 250 species, is poorly represented in Macaronesia. Its archipelagos harbour only 13 species belonging to the only two genera known in the Palaearctic region, Tychius Germar, 1817 and Sibinia Germar, 1817. Among these species only three are endemic, the others being mainly of European, Mediterranean and North African distribution. Up to now, in the Macaronesian archipelagos Tychiini are unknown from the Cape Verde Islands and Selvagens, whereas the group has its largest number of species in the Canaries (10), followed by the Azores (2) and Madeira (1). The only species of Tychiini reported so far from Madeira is T. filirostris Wollaston, 1854, which was only known from two females collected on the island of Porto Santo and is seemingly endemic to this archipelago.

This study reports new material of T. filirostris and two new species records from the Madeira archipelago: Tychius bicolor Brisout, 1862 from Madeira and Sibinia arenariae Stephens, 1831 from Porto Santo. In addition, examination of Wollaston's holotype and two new specimens of T. filirostris and their comparison with the holotype, paratypes and other specimens of T. colonnellii Caldara, 1991 from the Canary Islands (Tenerife, La Palma) and Selvagen Pequena (new record) have led to the establishment of a new synonymy. Thus, T. colonnellii, considered endemic to the Canary Islands archipelago, is sunk into synonymy with T. filirostris. A checklist of all the species of Tychiini present in the archipelagos of Macaronesia is presented.

\section{Tychius filirostris Wollaston}

Tychius filirostris Wollaston, 1854: 346; 1857, 111; Caldara 1990: 142.

Tychius colonnellii Caldara, 1991: 185 syn. n.

Material examined. Porto Santo, Campo de Cima, 3.vi.2000, leg. D. Aguín Pombo, 1 male, 1 female (coll. University of Madeira).

The two new specimens differ a little from each other, since the male is characterized by elongate subrectangular elytra and a dorsal vestiture of nearly unicolorous whitish-grey scales, whereas the female has shorter, oval elytra and the dorsal vestiture medially with reddish brown scales and laterally with whitish ones. Due to these characters, the female is very similar to the holotype of T. filirostris as redescribed by Caldara (1990), whereas the male seems intermediate between the holotype of $T$. filirostris and that of $T$. colonnellii, a taxon described from Teno at Tenerife and collected on Lotus glaucus Aiton (Caldara 1991). The same variability was found in other short series of specimens from the Canary Islands examined after the description of T. colonnellii; those collected in Tenerife (Lomo del Mormillo, on Lotus sp., leg. M.G. Morris) are similar to the holotype of T. filirostris whereas those collected at La Palma Island (Tagoja Mt., on 
Lotus campylocladus Webb \& Bert., leg. M.G. Morris) are more similar to the type series of T. colonnellii. Due to a lack of differences other than the shape of the elytra and the colour of the dorsal vestiture, we interpret all these specimens as belonging to a single variable taxon, the holotypes of $T$. filirostris and $T$ colonnellii representing the two extremes of the range of its variability. We therefore conclude that $T$. colonnellii is a junior synonym of $T$. filirostris. Moreover, it is noteworthy that we examined also one male Tychius specimen collected on Selvagen Pequena Island (leg. A. Serrano), from where no species of Tychius were previously reported; this specimen has a very dense elytral vestiture but is otherwise similar to the holotype of T. filirostris.

TABLE 1. Tychiini of Macaronesia archipelagos: distribution and references. Abbreviations: Madeira (Ma); Canary Islands (Ca); Selvagens (Sel); Azores (Az).

\begin{tabular}{|c|c|c|c|c|c|c|}
\hline Species & $\mathrm{Ma}$ & $\mathrm{Ca}$ & Sel & $\mathrm{Az}$ & Distribution & References \\
\hline Tychius (Tychius) antoinei Hustache, 1932 & & $\mathrm{x}$ & & & North-west African & Caldara, 1990 \\
\hline T. (T.) bicolor Brisout, 1862 & $\mathrm{x}$ & & & & South Palaearctic & this work \\
\hline T. (T.) cuprifer (Panzer, 1799) & & & & $\mathrm{x}$ & South-west Palaearctic & Borges et al., 2006 \\
\hline T. (T.) depauperatus Wollaston, 1864 & & $\mathrm{x}$ & & & North African & $\begin{array}{l}\text { Wollaston, } 1864 ; \\
\text { Caldara, } 1990\end{array}$ \\
\hline T. (T.) elongatulus Desbrochers, 1897 & & $\mathrm{x}$ & & & South Mediterranean & Caldara, 2007 \\
\hline T. (T.) filirostris Wollaston, 1854 & $\mathrm{x}$ & $\mathrm{x}$ & $\mathrm{x}$ & & endemic & $\begin{array}{l}\text { Wollaston, } 1854 \text {, } \\
1857 \text { (Ma); Caldara, } \\
1991 \quad(\mathrm{Ca}) ; \quad \text { this } \\
\text { work (Ca, Ma, Sel) }\end{array}$ \\
\hline T. (T.) picirostris (Fabricius, 1787) & & & & $\mathrm{x}$ & Holarctic & Borges et al., 2006 \\
\hline T. (T.) stephensi Schönherr, 1836 & & $\mathrm{x}$ & & & Holarctic & $\begin{array}{l}\text { Machado \& Oromi, } \\
2000\end{array}$ \\
\hline T. (T.) striatulus Gyllenhal, 1836 & & $\mathrm{x}$ & & & Mediterranean & Caldara, 1990 \\
\hline Sibinia (Dichotychius) albosquamosa Pic, 1904 & & $\mathrm{x}$ & & & South Mediterranean & Caldara, 1979 \\
\hline $\begin{array}{l}\text { S. (D.) planiuscula planiuscula Desbrochers, } \\
1873\end{array}$ & & $\mathrm{x}$ & & & Mediterranean & Caldara, 1979 \\
\hline S. (Sibinia) arenariae Stephens, 1831 & $\mathrm{x}$ & $\mathrm{x}$ & & & South Palaearctic & $\begin{array}{l}\text { Morris, } 2007(\mathrm{Ca}) \\
\text { this work }(\mathrm{Ma})\end{array}$ \\
\hline S. (S.) sericea Wollaston, 1864 & & $\mathrm{x}$ & & & endemic & $\begin{array}{l}\text { Wollaston, } 1864 ; \\
\text { Caldara, } 1984\end{array}$ \\
\hline
\end{tabular}

The two specimens from Porto Santo were collected on the north-eastern coast of the island on grasses growing on sandy ground near a cliff, at about $90 \mathrm{~m}$ altitude and close to a garbage station. Porto Santo is a tourism resort, mainly for habitants of Madeira, but recently there has been intensive construction to increase the number of hotels and other facilities (e.g,. golf courses, roads, etc.) to attract foreign tourism. This has resulted in great modification of natural habitats. Coastal habitats, especially those of T. filirostris, are under great pressure and measures should be undertaken to avoid the loss of this species on this Island.

\section{Tychius bicolor Brisout}

Tychius bicolor Brisout, 1862: 772; Caldara 1990: 178.

Material examined. Madeira, Ajuda, Funchal, 50 m, 18.v.2003, leg. R.A. Reis, 1 male (coll. University of Madeira). This species has a large southern Palaearctic distribution, being known from the Iberian Peninsula and Morocco in the west to Afghanistan in the east (Caldara 1990). However, up to now it has never been reported from Macaronesia. In 
France and Italy it lives on Melilotus spp., usually M. officinalis L. (Caldara 1990), but it has also been collected on Astragalus monspessulanus L. (Hoffmann 1954) in France. At the end of April 2007 we visited Ajuda and located several flowering plants of M. officinalis, but unfortunately without being able to collect any weevils on them.

\section{Sibinia arenariae Stephens}

Sibinia arenariae Stephens, 1831: 58; Caldara 1985: 74; 1987: 39; Morris 2007: 10.

Material examined. Porto Santo Island, Pico do Maçarico, 12.iii.2006, leg. M. Tedeschi, 2 females (coll. Tedeschi).

This species is widespread in the whole Palaearctic Region except for Japan (Caldara 1985, Caldara 1987) but has also never been reported from the Madeiran Archipelago. Morris (2007) recently re-examined specimens collected in the Canary Islands (Lanzarote) identified as S. primita (Herbst, 1795) and reported under this name in the checklist of Machado \& Oromí (2000), and he concluded that they actually represent S. arenariae. In 1995 and 2005 he had collected other specimens of $S$. arenariae from a number of localities in Lanzarote. In Europe and North Africa this species lives on various species of Spergularia and Spergula. It was collected in the south-eastern part of Porto Santo near the coast on Pico Maçarico at $285 \mathrm{~m}$ altitude, by netting low grasses growing on sandy ground (Tedeschi pers. com.).

\section{Acknowledgments}

We wish to thank Michael G. Morris (Natural History Museum, London) and Michele Tedeschi (Milan) for allowing us to use their material and the former also for some corrections on the manuscript.

\section{References}

Borges, P.A.V., Oromi, P., Dinis, F. \& Jarroca, S. (2006) Coleoptera. In: Borges, P.A.V, Cunha, R., Gabriel, R., Martins, A.F, Silva, L. \& Vieira, V. (eds), A list of the terrestrial fauna (Mollusca and Arthropoda) and flora (Bryophyta, Pteridophyta and Spermatophyta) from the Azores, Direcção Regional do Ambiente and Universidade dos Açores, Horta, Angra do Heroísmo and Ponta Delgada, pp. 197-207.

Brisout, C. (1862) Méthode dichotomique appliquée aux Tychius de France et description de quelques espèces nouvelles des genres Tychius et Miccotrogus. Annales de la Société Entomologique de France, 2(4), 756-779.

Caldara, R. (1979) Revisione delle specie paleartiche di Sibinia vicine a sodalis Germar ed exigua Faust (Coleoptera Curculionidae). Memorie della Società Entomologica Italiana, 57, 65-100.

Caldara, R. (1984) Revisione delle Sibinia paleartiche (Coleoptera Curculionidae). Memorie della Società Entomologica Italiana, 62/63, 24-105.

Caldara, R. (1987) Addenda alla revisione delle Sibinia paleartiche (Coleoptera Curculionidae). Bollettino della Società entomologica Italiana, 119, 35-44.

Caldara, R. (1990) Revisione tassonomica delle specie paleartiche del genere Tychius Germar (Coleoptera Curculionidae). Memorie della Società Italiana di Scienze Naturali e del Museo Civico di Storia Naturale di Milano, 25, 51218.

Caldara, R. (1991) Tychius colonnellii nuova specie delle Isole Canarie (Coleoptera, Curculionidae). Fragmenta Entomologica, Roma, 23, 185-189.

Caldara, R. (2007) On two species of Curculionidae (Col.) new to the Canary Islands. Entomologist's Monthly Magazine, 143: 200.

Hoffmann, A. (1954) Coléoptères Curculionides (deuxième partie). Faune de France 59. Lechevalier, Paris, pp. 4871207.

Machado, A. \& Oromí P. (2000) Elenco de los coleópteros de las Islas Canarias. Instituto de Estudios Canarios, La Laguna, 306 pp.

Morris, M.G. (2007) Sibinia arenariae Stephens, not S. primita (Herbst), in Lanzarote, Canary Islands (Col. Curculionidae). Entomologist's Monthly Magazine, 143, 10.

Stephens, J.F. (1831) Illustrations of British entomology. 4. Mandibulata. Baldwin \& Cradock, London, 414 pp.

Wollaston, T V. (1854) Insecta Maderensia; being an account of the insects of the islands of the Madeiran group. John van Voorst, London, xliii + 634 pp., XIII pls.

Wollaston, T.V. (1857) Catalogue of the Coleopterous Insects of Madeira in the Collection of the British Museum. Taylor 
\& Francis, London, 234 pp., I pl.

Wollaston, T.V. (1864) Catalogue of the Coleopterous insects of the Canaries in the collection of the British Museum.

Taylor \& Francis, London, xiii + 648 pp 